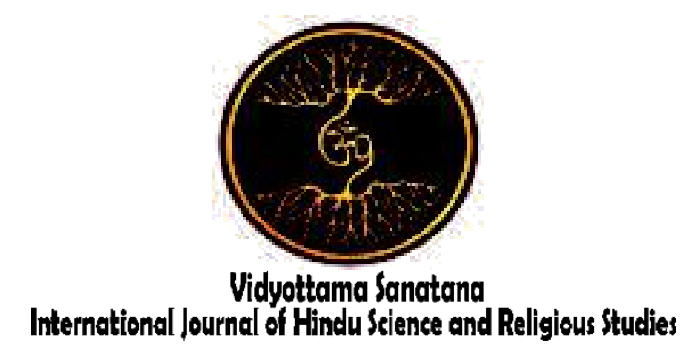

Vol. 3 No. 1 May 2019

\title{
DEVELOPING SPIRITUAL BEHAVIOR THROUGH YOGA TRAINING
}

\author{
By: \\ I Ketut Sudarsana \\ Institut Hindu Dharma Negeri Denpasar \\ E-mail : iketutsudarsana@ihdn.ac.id
}

\begin{tabular}{|l|l|l|}
\hline Received: September 23, 2019 & Accepted: May 01, 2019 & Published: May 31, 2019 \\
\hline
\end{tabular}

\begin{abstract}
This study aims to discover the extent of yoga training can foster spiritual behavior, especially at Ashram Gandhi Puri Klungkung. Yoga is a way to achieve harmony between the physical body, mind and spirit, where yoga movements can affect physically and mentally to be healthy. yoga activity is expected to form a spiritual behavior, ie, moral, mental, and spiritual good. Based on the results of the study, spiritual behaviors that impacted yoga training included practicing tri kaya parisudha, panca yama bratha, panca nyama bratha, dasa yama bratha, dan dasa nyama bratha.
\end{abstract}

Keywords: Spiritual Behavior, Yoga Training

\section{Introduction}

Humans as individual beings are unity between soul and body, unity between psychic and physical, so that there is an expression, that in a healthy soul there is a healthy body and in a healthy body there is a healthy soul. Humans as social beings means that in this life humans interact with each other and with the natural surroundings. Society as a place to live with each individual interwoven and bonded to one another in relation to social interaction, then pass through a process of socialization with communication. Humans as spiritual beings, meaning humans are fully aware that the universe with all its contents is the creation of God Almighty. Among God's creatures, only humans are perfect, because they have advantages such as: humans have the power of creativity, power and intention, so that humans can develop themselves full of the dynamics of being virtuous human beings. Humans can improve the status and dignity, 
whether in fulfilling the need of physical / temporal and spiritual needs.

Yoga is an interesting thing to discuss, because yoga is universal and quite popular among people both Hindus and other people. Yoga which is one part of sad darsana, is now studied by most of the world's population. Not only Hindus are interested in practicing yoga, but also many outsiders who are interested in practicing yoga. Although yoga is already well known, it turns out that there are not too many Balinese who study yoga as a whole. In fact, yoga is one of the teachings of Hinduism, yet Balinese people who are mostly Hindus are not so enthusiastic to learn yoga. This happens, because yoga teachings are not widely socialized. Though the success and failure of a person in achieving something desired, much is determined by his ability to communicate that is fundamental in human life (Cangara, 2009: 3-4).

Yoga as a practical and philosophical teaching should be applied in its entirety and wholeness, from a yoga teacher, yoga student, and teaching media to achieve kaivalya or absolute liberation. The concept of Rsi Patanjali which is classical yoga based on physical, mental and spiritual training in directly understanding self-realization (spiritual enlightenment), as a whole is contained in Astangga Yoga (yama, nyama, asana, pranayama, dharana, dyana, dan samadhi) According to the teachings of yoga, yoga teachings are classified as a systematics and moral training, physical training, mental training, spiritual training and samadhi (Motoyama, 2003: 32).

When talking about yoga teachings with others, both verbal and nonverbal, this shows that humans exist. This needs to be developed in the Hindu community, with the emergence of spiritual groups and institutions, such as the Ashram, Yoga Center, Pasraman, etc. (Riswandi, 2009: 16)

Ashram Gandhi Puri Klungkung is one of the non-formal institutions engaged in spreading the teachings of M.K Gandhi associated with peace, simplicity and brotherhood. This ashram is located in Paksebali Village, Klungkung Regency.

Yoga that is applied in the Gandhi Puri Klungkung Ashram is yoga health in addition to fostering spiritual behavior. Health yoga includes elements of motion, breathing and meditation. It is very exciting and no other Ashram which characterizes Ashram Gandhi Puri Klungkung doing yoga activities. Yoga activities at Ashram Gandhi Puri Klungkung are so flexible and do not come out of the concept expressed from ancient writings on yoga by Patanjali, there is a short definition that mentions "Stiram sukham asanam" (yoga sutra II.46) which means body posture should be steady and comfortable (Saraswati, 2005: 292). With various types of laughter in yoga activities, which give rise to impacts / benefits, which later can form spiritual behaviors according to the philosophy of tri kaya parisudha.

In addition to providing the programs, the Gandhi Puri Klungkung Ashram also gave enlightenment given by spiritual leaders both local, national and foreign. Research is very important which is expected to eventually provide spiritual innovation as a mirror struggles that continue to occur according to the circumstances of either crash into the outside or from within according to the times that need attention. The community then becomes familiar with the practice of yoga so that it can shape a spiritual behavior by studying yoga thoroughly.

\section{Methods}

This study refers to the qualitative research, where the research location is Ashram Gandhi Puri Klungkung. Determination of informants using purposive sampling method that is selecting informants with a purpose basis, the measure used is the understanding of informants about the problems they want to research and believe to be a solid source. Data collection methods used are observation, interviews, and literature reviews. While the data analysis method follows the steps as follows: 
1. Data reduction: the process of collecting data in research related to data in the form of verbal descriptions captured by their meaning. This report is then inventoried by typing in a detailed description and report. This report is reduced in the sense that it is summarized, sorted out the main things focused on the important things, sought the substance and patterns.

2. Data classification: the results of the data reduction direct the researcher to find out the essential maps that concern the content of meaning in the data, then do the data classification which is grouping the data based on the characteristics of each research object.

3. Data display: organizing data in a map that is consistent with formal objects and research objectives.

4. Provide interpretation and draw conclusions: data in the form of verbal descriptions are always given interpretation and meaning. After the data is interpreted then an interpretation is given according to the context of the data that has been collected. After that a conclusion was drawn as part of the final stage of the study.

\section{Results and Discussion}

The implementation of yoga training at the Gandhi Puri Klungkung Ashram, is directed at the cleansing of the heart and mind so that it can become one with God. Its been a long tone when there is an assumption that God cannot be approached and cannot be understood, or other assumptions say that God must be feared off, because He will judge for all mistakes. This false assumption will only distance itself from Him. Through meditation, the soul will experience real communication with God and then obtaining all forms of relationships with Him, all the desired experiences, will be obtained in the relationship with God (Sudarsana, 2016).
The Godly training values described in yoga activities at Gandhi Puri Klungkung Ashram are God's relationship with souls who get all forms of relationships with the path of yoga. In the teachings of Hinduism the main conception of the doctrine of divinity is sraddha, which is convinced of God Almighty. Many facts that led to that belief arose based on the teachings of pramana religion that is by reading the holy books of the Vedas or listening to the stories about the truth through other people who deserved to be trusted. Referring to the research carried out, the spiritual behavior through yoga training at Gandhi Puri Klungkung Ashram is implemented in spiritual behavior as follows:

\section{Practicing the Teachings of Tri Kaya Parisudha}

The Concept of tri kaya parisudha in Gandhi Puri Klungkung Ashram has specifically entered into the daily practice of every activity at the ashram. Because to get practical benefits that must be done, to what extent it is understood and then implemented.

Everything that people do can take place through trikaya, three limbs, namely: kaya, wak and manah. kaya are members of the body, such as hands, feet, back, mouth and so on, while wak are words and manah is the mind (Sura, 2001: 94). With these three tools, humans can do something, both for themselves and for others, as well as their environment.

Three members of the body can be used for bad purposes and can also be used for good purposes, then trikaya will be called tri-kaya parisudha means three consecrated limbs include:

\section{a. Kayika Parisudha}

Kayika parisudha can be formulated as any behavior related to a purified body. By doing means has made a karma that will determine life in the future. Because if you expect a better life on the day to come, then now is the time to plant good karma by avoiding bad deeds. The example practice of 
kayika parisudha is: mutual help, develop tolerance, respect, and so on.

\section{b. Wacika Parisudha}

Saying right and good is called wacika parisudha. Almost every day people speak, chat or communicate to convey their hearts to others. Knowledge is mostly obtained through words, both verbally and in writing. Thus the words have a very important position and role in life, therefore we should be able to control ourselves when speaking so that the words are good, true and useful words for life. The example practice of wacika parisudha is: say politely, don't say harshly, say honestly, and so on.

\section{c. Manacika Parisudha}

Manacika parisudha is think good and right (sanctified). The mind gets great attention in the teachings of yoga, because the mind is the source of what people say. If the mind tells the limbs to be silent, then the limbs are still, if the mind tells the mouth not to say, then the mouth is silent. The mind determines all people's actions. Thus controlling the mind and directing things that are good and noble means to annihilate one's own personality as a whole and eventually will bring yourself to peace and holiness. The example practice of manacika parisudha is: positive thinking, good thinking, optimistic thinking, and so on.

Based on the three quotations above regarding to tri kaya parisudha, it can be stated that tri kaya parisudha is a concept of giving guidance. So that people always do good and right, honest, obedient, holy, satya (according to law), seken/saja (earnestly) and balanced between mind, words and deeds. If it is implemented in accordance with the concept, tri kaya parisudha can certainly grow the life of an honest and balanced, thus bringing life towards living in harmony and peace, although participants heterogeneity in Ashram Gandhi Puri Klungkung.

\section{Practicing the Doctrine of Panca Yama Bratha}

Panca yama bratha is five types of initial self-control called mahavrata "Glorious Pledge", "ahimsa satasteya brahmacaryaparigraha yamah" (Yogasutra. II: 30) which means as follows:

a. Ahimsa means not behaving and acting harsly on fellow leving beings through thought, speech as well as action.

b. Satya means to have a good attitude and behavior, righteous on mind, faithful to the words and honest with the deeds.

c. Asteya means not stealing or wanting other people's property.

d. Brahmacarya means to act and behave in a controlled manner, controlling romance.

e. Aparigraha means living a simple life not greedy. Be able to accept the reality of life as it is. Only accept what is truly needed (Sukayasa, dkk, 2006 : 54).

The description above concerns the spiritual behavior carried out by participants in yoga activities at Ashram Gandhi Puri Klungkung in this matter Panca Yama Bratha. This teaching becomes a guidance/ life guidance of the participant in carrying out self-control or restraint on lust at the first lever, emphasizes physical control. For example: the Participant are taught not to kill, except for offerings and if those animals are dangerous for human. Furthermore, they taught to utilize the learning period to study at best. They are taught to be faithful and keep promises. They are taught not to be bound by worldliness and at the the end they were taught not to want the property of others. Therefore, the self-control is not only carried out in yoga activities at the Ashram Gandhi Puri Klungkung, but also implemented in daily life.

\section{Practicing the Teaching of Panca Nyama Bratha}

Panca Nyama Bratha is five types of advanced self-control to confirm the yama bratha. In Yogasutra (II:32) stated that 
"Sauca santosa tapah svadyayesvara pranidha nityamah" which means :

a. Sauca means trying to maintain the purity and cleanliness of both physically and inner self.

b. Santosa means trying to maintain the stability of emotion to always be calm, wise, and peaceful. Not troubled by life problems.

c. Tapa it means trying to resilient, unyielding and cling to dharma.

d. Swadhaya means trying to learn independently, diligently studying the scriptures.

e. Iswarapranidhana means always trying for focusing the mind and devotion towards Iswara (God) (Sukayasa, dkk, 2006: 56 )

Through applying various methods of self-control above, it is hoped that a yoga practitioner will gain success. The characteristics of people who succeed in yoga are as follows:

a. Spread love and other high spiritual qualities to others.

b. Not wasting Virya (sexual energy)

c. Be able to control the senses and mind well

d. Like to do service (seva) to human kind without ulterior motives.

e. Be friendly to everyone

f. Reach the spiritual enlightment

g. Not doing spree, drunk prostitute, gamble, including all low as well as stupid behavior.

h. Not hurting other people's feelings, no pleasure or sorrow towards anyone (Yupardi, 2004: 24-25).

The description above concern the spiritual behavior carried out by participant in yoga activities at Anstam Gandhi Puri Klungkung, in this matter the panca nyama bratha. This teaching is the guideline of life guidance of the participant in carrying out self-control or restraint in lust at an advance level after carrying out the teachings of the panca yama bratha. The teaching of panca nyama bratha emphasizing the spiritual control. For example: the participant are taught not to be angry; then they are taught to respect and have devotion towards Teachers (Guru); they are taught to be holy physically and mentally; participants are taught to adjust their diet according to their body needs; and the last one, they are taught to not neglecting their duty especially their personal duty. Therefore, self-control is not only carried out in yoga activities at Ashram Gandhi Puri Klungkung, but also implemented in daily life.

\section{Practicing the Teaching of Dasa Yama Bratha}

Dasa Yama Bratha are ten selfcontrol or restraint of lust which is done by everyone while wading through the sea of life in order to achieve eternal happiness in the hereafter (moksa), its parts namely :

a. Anresangsya means selflessness or not selfish

b. Ksama means are like to forgive others and hold the test

c. Satya means honest and loyal so that it pleases parents as well as always being loved in society

d. Ahimsa means not torture or kill innocent or guilty living beings

e. Dama means be able to advise themselves, be able to control their senses.

f. Ajarwa means be able for defending the truth

g. Priti means love and affection for fellow living beings

h. Prasada means have a pure thinking and pure heart without strings attached.

i. Madurya means have hospitality and courtesy.

j. Mandharwa means humble and not arrogant (Yuliastini, 2010: 68).

The descriptions above concerns the spiritual behavior carried out by participant in yoga activities at Ashram Gandhi Puri Klungkung, in this matter the Dasa Yama Bratha. The teaching of Dasa Yama Brata is ten kinds of basic level of self-control to achieve perfection of life. For example the participants are taught to prioritize the public interest over personal interests, forgive 
friends' mistakes, realize wrong actions, words and deeds, do not confess and feel themselves always right, diligently care for and cultivate plants, honest and loyal to every action, etc. Therefore, self-control is not only carried out in yoga activities at the Ashram Gandhi Puri Klungkung, but also implemented in daily life.

\section{Practicing the Teaching of Dasa Nyama Bratha}

The spiritual behavior formed in Yoga activities at the Ashram Gandhi Puri Klungkung namely Dasa Nyama Bratha which also known as ten types pf self-control or mental attitudes. In Sarasamuscaya sloka 260 it is stated that: This ten bratha are called nyama with detailed as : Dana, Ijya, Tapa, Dharma, Upasthanigraha, Bratha, Upawasa, Mona, Swadhyaya, Snana, each of them can be described as follows :

a. Dana means giving punia. Those who like charity will get reward from Ida Sang Hyang Widhi Wasa. In Sarasamuscaya 261-262 stated that : the way to get something should be based on dharma. Funds obtained should be divided into three, namely to meet the kama and to carry out activities in the field of economic business in order to grow again.

b. Ijya means respect for ancestors and parents

c. Tapa means training yourself in order to achieve peace of mind and inner peace. In Sarasamuscaya 103 mentioned: this is what is considered carefully should always be held firm and carried out diligently.

d. Dharma means keen to focus on the mind, feeling and intention towards Ida Sang Hyang Widhi Wasa.

e. Upasthanigraha means always controlling the lust

f. Bratha means restraining yourself from food and drink or obeying vows and promises.

g. Upawasa means fasting on certain days h. Mona means limiting words, not acting arbitrarily, not talking about unimportant things.

i. Swadhaya means diligently study and explore the scriptures and other knowledge.

j. Snana means diligently doing selfpurification (Kadjeng, dkk, 2005: 130-131)

The description above, concerning spiritual behavior carried out by participants in yoga activities at Ashram Gandhi Puri Klungkung in this matter, the teaching of Dasa Nyama Bratha. This teaching is the ten types of advanced self-control to achieve the perfection of life. Therefore, self-control is not only carried out in yoga activities at the Ashram Gandhi Puri Klungkung, but also implemented in daily life.

\section{Conclussion}

Growing spiritual behavior in this study is able to make yoga participants in their activities in accordance with the joints of spiritualism, the depth of one's religious appreciation and belief in the existence of God which is realized by obeying the commandments and away from prohibitions with sincerity of heart and with all soul and body. For the happiness of life and harmony between human relations with God Almighty, between fellow humans, humans and the universe, and His creation through yoga activities in Ashram Gandhi Puri Klungkung.

\section{References}

Cangara, H. (2009). Pengantar Ilmu Komunikasi. Jakarta: Raja Grafindo Persada

Kadjeng, I N. (2005). Sarasamuccaya. Surabaya: Paramita.

Motoyama, H. (2003). Theories of The Chakras Bridge To Higher Consciousness. New Delhi: Neg Age Books.

Riswandi. (2009). Imu Komunikasi. Yogyakarta: Graha Ilmu. 
Sarasvati, S. S. P. (2005). Patanjali Raja Yoga (J.B.A.F. Mayor Polak Penerjemah). Surabaya: Paramita.

Sudarsana, I. K. (2016). Development Model of Pasraman Kilat Learning To Improve The Spiritual Values of Hindu Youth. Jurnal Ilmiah Peuradeun, 4(2), 217-230.
Sukayasa, I W. (2006). Yoga Marga Rahayu. Denpasar: Widya Dharma.

Sura, I G. (2001). Pengendalian Diri dan Etika Dalam Ajaran Agama Hindu. Jakarta: Hanuman Sakti.

Yupardi, W. S. (2004). Disiplin dan Sadhana Spiritual. Surabaya: Paramita. 